\title{
Chemical profiling and cytotoxic activity of aqueous extract of Veronica peduncularis M.Bieb.: A chemotaxonomical approach
}

\author{
Zeynep Doğan ${ }^{1}$ (D), Yasin Genç ${ }^{1}$ (D) Ümmühan Șebnem Harput ${ }^{2}$ (D), Asuman Karadeniz Pekgöz ${ }^{3}$ (D), \\ İclal Saraçoğlu ${ }^{1}$ \\ ${ }^{1}$ Hacettepe University, Faculty of Pharmacy, Department of Pharmacognosy, Ankara, Turkey, \\ ${ }^{2}$ Professor of Pharmacognosy, Independent Researcher, Ankara, Turkey \\ ${ }^{3}$ Mehmet Akif Ersoy University, Faculty of Science and Art, Department of Biology, Burdur, Turkey
}

ORCID IDs of the authors: Z.D. 0000-0002-0108-6040; Y.G. 0000-0002-5408-7565; Ü.Ș.H. 0000-0002-2641-3263;

A.K.P. 0000-0002-8141-7849; I.S. 0000-0003-0555-6262

Cite this article as: Dogan, Z., Genc, Y., Harput, U. S., Karadeniz Pekgoz, A., \& Saracoglu, I. (2021). Chemical profiling and cytotoxic activity of aqueous extract of Veronica peduncularis M.Bieb.: A chemotaxonomical approach. Istanbul Journal of Pharmacy, 51 (3), 372-377.

\begin{abstract}
Background and Aims: Genus Veronica (Plantaginaceae) is represented by 79 species in Turkish flora, 26 of which are endemic. Veronica species have a variety of uses including diuretic, anticancer, and rheumatic pains, wounds, and respiratory problems. According to phytochemical studies, Veronica species contain predominantly iridoid glucosides with some phenylethanoid and flavonoid glycosides.

Methods: The aqueous extract of Veronica peduncularis M.Bieb. was tested for its cytotoxic activity on human rhabdomyosarcoma (RD) and human epidermoid carcinoma (HEp-2) cell lines using the MTT method. Chemical profile of the extract was determined by HPLC-DAD, and isolation studies were conducted.

Results: The extract was found to show concentration-dependent cytotoxicity against tested cell lines. In addition, a comparison of the iridoid fraction of Veronica peduncularis with previously isolated iridoid glucosides on the HPLC-DAD system, showed the presence of aucubin, amphicoside, veratroyl catalpol, and veronicoside in this fraction. On the other hand, isolation and structure elucidation of plantamajoside and 4'-0-methylisoscutellarein-7-0-2"'-0-(6'"'-0-acetyl- $\beta$ - D-allopyranosyl)$\beta$ - $D$-glucopyranoside from the phenolic fractions were performed by serial chromatographic and spectroscopic methods. Conclusion: To the best of our knowledge, this is the first cytotoxic activity and phytochemical study on the titled plant. The presence of iridoid glucosides and 8-hydroxyflavone glycosides is important for the chemotaxonomy of the genus Veronica.

Keywords: 4'-O-methylisoscutellarein-7-O-2"'-O-(6"'-O-acetyl- $\beta$ - $D$-allopyranosyl)- $\beta$-D-glucopyranoside, HPLC, iridoid glucosides, phenolics, plantamajoside, Veronica
\end{abstract}

\section{INTRODUCTION}

Genus Veronica formerly a member of the Scrophulariaceae family, was moved to Plantaginaceae after phylogenetic and chemotaxonomic studies (Olmstead, 2002). The genus is represented by 79 species in the flora of Turkey, 26 of which are endemic (Fischer, 1978).

Veronica species have been used as a diuretic, expectorant, antiscorbutic, and in the treatment of rheumatic pains, wounds, cough, and influenza in Turkish traditional medicine (Baytop, 1999; Fujita et al., 1995; Harput, Genc, Khan, \& Saracoglu, 2011).

Address for Correspondence:

Zeynep DOĞAN, e-mail: zeynep.ocak@hacettepe.edu.tr

This work is licensed under a Creative Commons Attribution 4.0 International License.
Submitted: 25.12 .2020

Revision Requested: 24.07.2021

Last Revision Received: 23.08.2021

Accepted: 16.09 .2021

Published Online: 00.00 .0000 
Additionally, there are various uses worldwide as an anticancer agent (Graham, Quinn, Fabricant, \& Farnsworth, 2000), against hemoptysis, laryngopharyngitis, and hernia (Salehi et al., 2019), irregular menstruation, and embolism (Xue, Chen, Zhang, \& Li, 2019). Phytochemical studies on the genus Veronica showed the presence of many iridoid glycosides, most of which are benzoic and cinnamic acid esters of catalpol, in addition to the presence of phenylethanoids and flavonoid glycosides (Harput et al., 2011; Saracoglu, Oztunca, Nagatsu, \& Harput, 2011; Saracoglu, Varel, Harput, \& Nagatsu, 2004). Biological activity studies on Veronica extracts showed their antimicrobial, antioxidant, cytotoxic, anti-tumour, antiinflammatory activities via in vitro and in vivo experiments (Harput, Saracoglu, Inoue, \& Ogihara, 2002; Salehi et al., 2019). Additionally, it is thought that Veronica can be used as a natural food preservative, considering its antimicrobial effects (Salehi et al., 2019).

In our previous studies, water extract from $V$. peduncularis was tested for its radical scavenging activity against different radicals such as 2,2-diphenyl-1-picrylhydrazyl (DPPH), superoxide (SO) and nitric oxide (NO) radicals, spectroscopically. Concentration dependent radical scavenging activity was observed and the results were found to be comparable to reference compounds; ascorbic acid, quercetin and $\mathrm{BHA}$. According to this study, $I C_{50}$ values of aqueous fraction were found as 54.2, 186.3, and $770 \mu \mathrm{g} / \mathrm{mL}$ for DPPH, NO and SO, respectively. $V$. peduncularis showed the highest activity against DPPH radical among the tested free radicals. In addition, gallic acid equivalent total phenolic contents of the plant were also determined using Folin-Ciocalteau reagent, and found as $139.9 \mathrm{mg} / \mathrm{g}$ dry extract (Harput, Karadeniz, Genc, \& Saracoglu, 2009).

It has been shown that free radicals damage DNA and this damage can cause many diseases, including cancer ( $\mathrm{NCl}$, 2020). Based on the moderate radical scavenging effect of this genus and their usage against cancer in traditional medicine, in the present study $V$. peduncularis was investigated for its cytotoxic effects. On the other hand, it is known that some of the iridoid glucosides, flavonoids, and phenyletanoid glycosides may be responsible for the anticancer properties of plants (Saracoglu \& Harput, 2012; Saracoglu, Inoue, Calis, \& Ogihara, 1995; Yin et al., 2016). Furthermore, iridoid glucosides are characteristic of the genus Veronica and play an important role in the reclassification of the genera in the families of Scrophulariaceae and Plantaginaceae (Jensen, Albach, Ohno, \& Grayer, 2005). Therefore, in the current study, the cytotoxic effect of aqueous extract of Veronica peduncularis was evaluated in addition to the determination of the chemical profile of the extract by HPLC-DAD for iridoid glucosides and isolation studies for phenolic compounds.

\section{MATERIALS AND METHODS}

\section{Plant materials}

Veronica peduncularis Bieb. (Plantaginaceae) was collected from Macka, Trabzon, Turkey. A voucher specimen (HUEF 09012) was deposited in the Herbarium of the Faculty of Pharmacy. The authentication of plant specimens was made by Serdar Aslan,
Duzce University, Duzce, Turkey (previous address: Gazi University, Ankara, Turkey).

\section{General}

Polyamide (50-160 um, Fluka, Seelze, Germany), Sephadex LH-20 (GE Healthcare, Chicago, IL, USA), and thin-layer chromatography (TLC) plate (Kieselgel 60 F254, 0.20mm, Merck, Darmstadt, Germany) were used in chromatography system. In vacuum liquid chromatography (VLC), samples were chro-

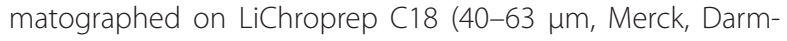
stadt, Germany). Minimum essential medium Eagle with Earl's salts (MEM) and Dulbecco's phosphate-buffered saline (DPBS) were obtained from Sigma-Aldrich Chemical Co. (St. Louis, MO, USA). Antibiotics (penicillin and streptomycin) and fetal bovine serum (FBS) and were purchased from Biochrom AG (Berlin, Germany).

\section{Preparation of extract and isolation of compounds}

The air-dried aerial parts of $V$. peduncularis (185 g) were extracted with $1 \mathrm{~L} \mathrm{MeOH}$ for four times at $40^{\circ} \mathrm{C}$. The combined extracts were evaporated under vacuum to give $45.8 \mathrm{~g}$ of crude $\mathrm{MeOH}$ extract. $\mathrm{MeOH}$ extract was dissolved in water and partitioned with petroleum ether to remove chlorophylls and other lipophilic compounds. The aqueous fraction (36.2 g) was subjected to polyamide column chromatography eluting with increasing concentrations of $\mathrm{MeOH}$. Fraction A (Fr. A, $9.8 \mathrm{~g}$ ) eluted with $\mathrm{H}_{2} \mathrm{O}$ was determined as iridoid fraction according to TLC characteristics. Fr. A was dissolved in water and partitioned with $n$-butanol to remove the sugar part of the fraction. The refined iridoid fraction was subjected to analytical HPLC analysis to determine the iridoid composition of the plant using previously isolated iridoid glucosides as reference compounds. Fr. B (0.9 g) eluted with 25\% methanol was subjected to vacuum liquid chromatography (45 g using $\mathrm{CH}_{3} \mathrm{OH}$ : $\left.\mathrm{H}_{2} \mathrm{O}, 0 \% \rightarrow 70 \%\right)$ to get 6 sub-fractions, Frs. B1-B6. Fr. B5 was applied to Sephadex LH 20 column (100\% methanol) to get plantamajoside (10.2 mg). Fr. D (0.5 g) eluted with 75\% methanol was subjected to vacuum liquid chromatography (45 g using $\left.\mathrm{CH}_{3} \mathrm{OH}: \mathrm{H}_{2} \mathrm{O}, 20 \% \rightarrow 70 \%\right)$ to obtain 15 sub-fractions, Frs D1D15. For purification of 4'-O-methylisoscutellarein-7-O-2"-O(6"'-O-acetyl- $\beta$-D-allopyranosyl)- $\beta$-D-glucopyranoside (7.8 mg), Fr. D12 was chromatographed on Sephadex LH 20 column (100\% methanol).

Plantamajoside (5): White amorphous powder. UV $\lambda_{\max }$ (MeOH) nm: 291, 330. NMR data are consistent with the literature (Kawada, Yoneda, Asano, Kan-No, \& Schmid, 2006; Ravn, Nishibe, Sasahara, \& Li, 1990; Zou et al., 2008).

\section{4'-O-Methylisoscutellarein-7-0-2"-O-(6"'-O-acetyl- $\beta$ -} $\boldsymbol{D}$-allopyranosyl)- $\boldsymbol{\beta}-\boldsymbol{D}$-glucopyranoside (6): Pale yellow amorphous powder. UV $\lambda_{\max }(\mathrm{MeOH}) \mathrm{nm}: 276,303,325$. NMR data are consistent with the literature (Albach, Grayer, Jensen, Ozgokce, \& Veitch, 2003; Lenherr, Lahloub, \& Sticher, 1984; Saracoglu, Harput, \& Ogihara, 2004).

\section{Determination of cytotoxicity by MTT method}

In the determination of the cytotoxic activity of the extract, MTT [3- (4,5-dimethylthiazol-2-yl) -2,5-diphenyl tetrazolium bromide] method developed by Mossman was used (Moss- 
man, 1983). Activity studies were performed on HEp-2 (Human Epidermoid Carcinoma) and RD (Human Rhabdomyosarcoma) series, which are cancer cells of human origin. Cells were incubated in MEM containing 10\% fetal bovine serum and 1\% penicillin/streptomycin solution. $100 \mu \mathrm{L}$ cell suspensions at a concentration of $1 \times 10^{5}$ cells $/ \mathrm{mL}$ for RD and HEp-2 were transferred to 96 well plates. After incubating for 24 hours in an incubator containing $5 \% \mathrm{CO}_{2}, 95 \%$ humidity at $37^{\circ} \mathrm{C}$, supernatant in the wells was aspirated and $100 \mu \mathrm{L}$ of extract solutions (200 and $400 \mu \mathrm{g} / \mathrm{mL}$ ) in the medium was added and kept in the incubator for another 48 hours. At the end of the period, the wells were washed with $100 \mu \mathrm{L}$ of medium and then $100 \mu \mathrm{L}$ of fresh medium was added to each well. $10 \mu \mathrm{L}$ of MTT solution in PBS (phosphate-buffered saline) at a concentration of $5 \mathrm{mg} /$ $\mathrm{mL}$ was added to each well and the wells were incubated for another 4-6 hours. During the incubation, the dehydrogenase enzyme in living cells reduced MTT to the purple formazan crystals. After incubation, $100 \mu \mathrm{L}$ of $10 \%$ SDS (Sodium dodecyl sulfate) solution was added to the wells and incubated for 20 hours to dissolve the formazan crystals. The absorbance was measured at 577/655 nm (Harput, Genc, \& Saracoglu, 2012; Saracoglu \& Harput, 2012).

\section{HPLC analysis}

HPLC analyses were carried out on a Dionex HPLC instrument system (Thermo Fisher Scientific, Waltham, MA, USA): P680 HPLC pump, Dionex ASI-100 autosampler, and Dionex Photodiode Array Detector. The column was Hichrom-Nucleosil

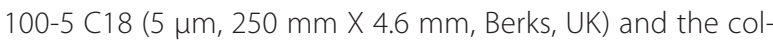
umn temperature was maintained at $27^{\circ} \mathrm{C} .20 \mu \mathrm{L}$ injection volume and $1 \mathrm{~mL} / \mathrm{min}$ flow rate were used for each experiment. Samples were passed through a $0.45 \mu \mathrm{m}$ filter and injected into the HPLC system. The mobile phase consisted of phosphoric acid (1\%) in water (solution A), and acetonitrile (solution B). The gradient system developed by authors was used for elution of samples as 95\% A, 5\% B for 0-15 min; $80 \%$ A, $20 \%$ B at $20^{\text {th }}$ min; $70 \%$ A, 30\% B at $45^{\text {th }}$ min, and then $67 \%$ A, $33 \% \mathrm{~B}$ at $52^{\text {nd }} \min$.

\section{RESULTS AND DISCUSSION}

In this study, the cytotoxic activity of $V$. peduncularis was evaluated on two cancer cell lines; HEp-2 and RD. The aqueous extract was tested at different concentrations, 200 and $400 \mu \mathrm{g} /$ $\mathrm{mL}$. While the extract showed slight cytotoxicity on $\mathrm{HEp}-2$ cells with the cell viability value of $89.87 \% \pm 3.6$ and $36.66 \% \pm 2.7$, it showed moderate cytotoxicity with $85.62 \% \pm 3.8$ and $8.43 \% \pm$
3.2 against RD cells at 200 and $400 \mu \mathrm{g} / \mathrm{mL}$, respectively (Figure 1). According to Saracoglu et al. (2011), cytotoxic activities of V. cuneifolia subsp. cuneifolia D. Don and V. cymbalaria Bodard aqueous extracts were tested on the same cell line, $I C_{50}$ values of extracts were found between $250.4-546.5 \mu \mathrm{g} / \mathrm{mL}$ with similar results to our results $\left(\mathrm{IC}_{50}: 230\right.$ and $390 \mu \mathrm{g} / \mathrm{mL}$ for $\mathrm{RD}$ and HEp-2, respectively). According to Harput et al. (2002), five different Veronica species; V. polita Fries, V. persica Poiret, V. hederifolia L., V. pectinata L. var. glandulosa Riek ex M.A., V. cymbalaria were tested for their cytotoxic effects on KB epidermoid carcinoma and B16 melanoma cells. In that study, it was found that chloroform fractions of methanolic extracts were more potent than the main methanolic extracts, although water-soluble portions didn't exhibit cytotoxic activity on the two tested cell lines.

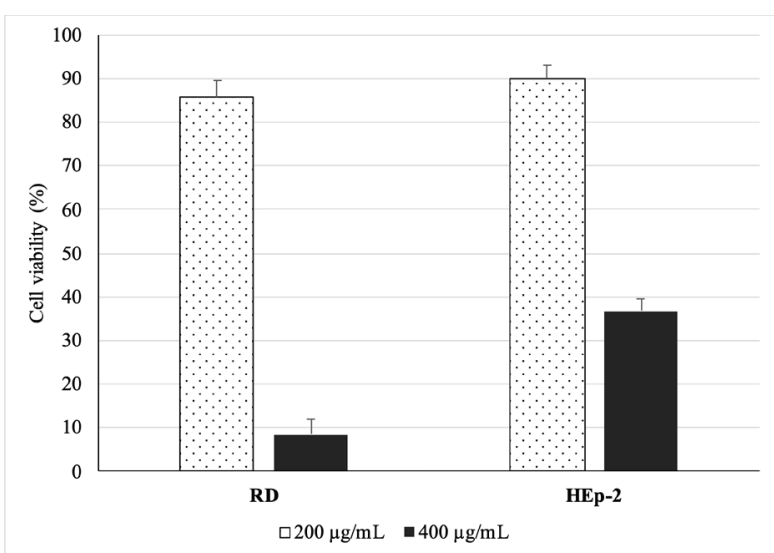

Figure 1. Cytotoxic activity of $V$. peduncularis aqueous extract.

Main iridoid glucosides of the iridoid fraction of the extract were determined with a specific HPLC-DAD method. The previously isolated iridoid glucosides from $V$. cymbalaria and $V$. cuneifolia subsp. cuneifolia, whose structures were elucidated by advanced NMR techniques, were used as reference (Saracoglu et al., 2011) (Figure 2). The comparison of the iridoid fraction with the reference compounds showed the presence of aucubin (1), amphicoside (2), veratroyl catalpol (3), and veronicoside (4) in this fraction (Figure 3). Their presences were confirmed by comparing their retention time and UV spectra with those of reference compounds (Figure 4). Iridoid glucosides are the most abundant constituents in Veronica species (Xue et al., 2019).

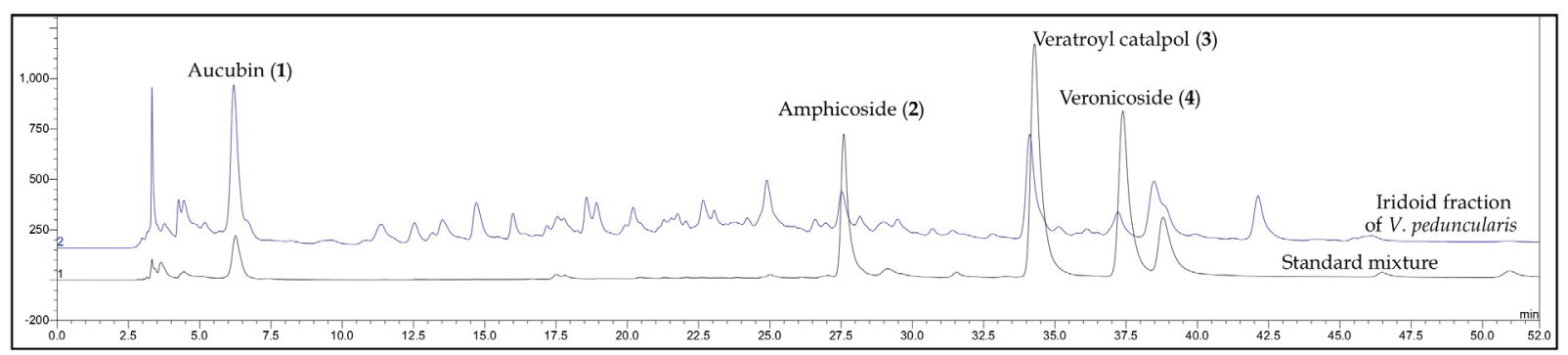

Figure 2. HPLC chromatogram of iridoid fractions from V. peduncularis and the mixture of reference iridoid glucosides (aucubin, amphicoside, veratroyl catalpol and veronicoside) at $200 \mathrm{~nm}$. 


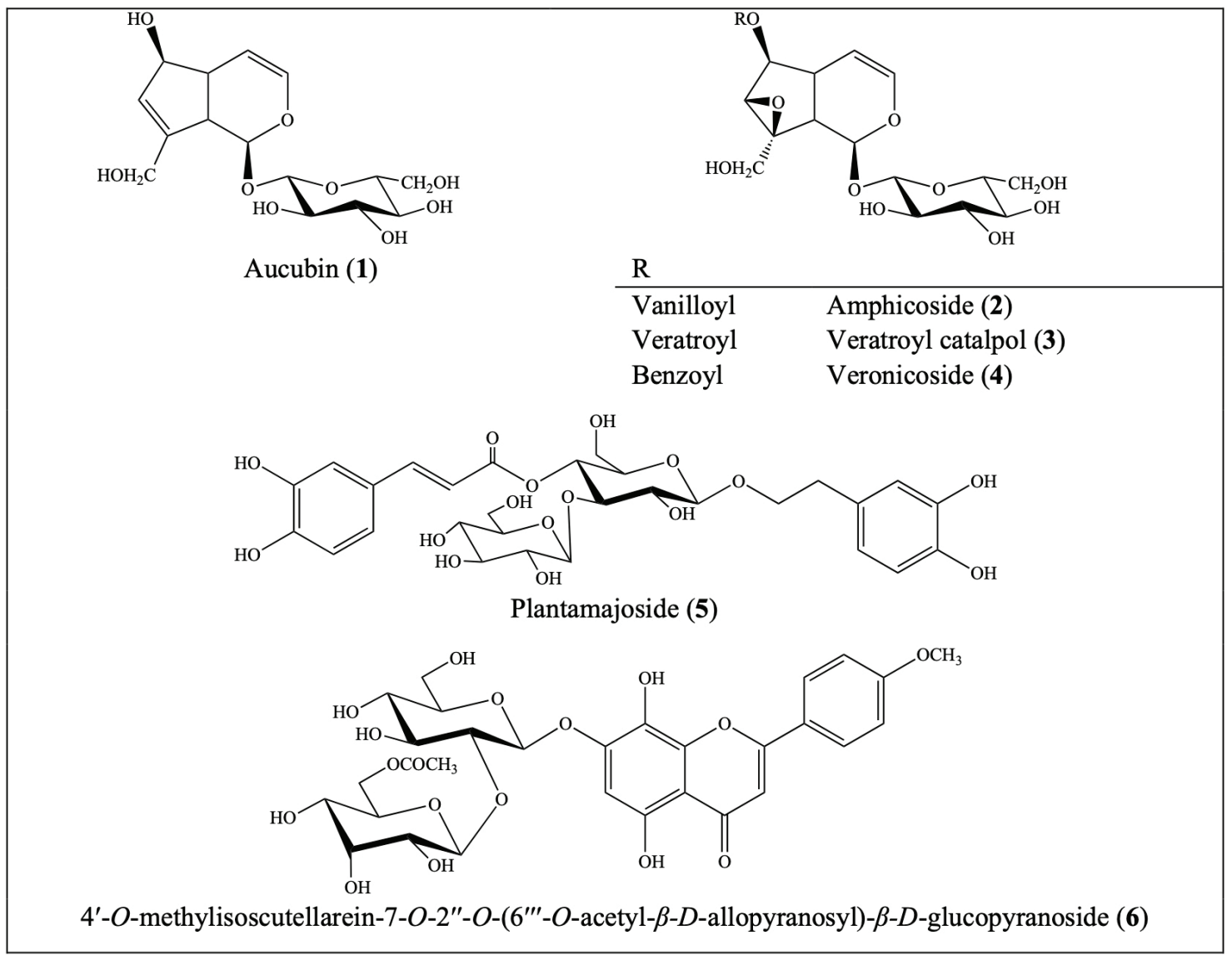

Figure 3. Structures of the compounds 1-6 determined and isolated from $V$. peduncularis.

Veronica species are classified into 4 sections; Chamaedrys, Alsinebe, Beccabunga, and Veronicastrum. V. peduncularis belongs to section Chamaedyrs (Fischer, 1978). It is known that 4-substituted iridoid glucosides are absent in section Chamaedrys (Saracoglu et al., 2011; Taskova, Albach, \& Grayer, 2004). In the present study, the HPLC results also support this knowledge about the lack of such molecules in section Chamaedrys.

Besides the chemotaxonomic importance of iridoid glucosides, they have also various biological effects as antitumor, anti-inflammatory, hepatoprotective, neuroprotective, hypoglycemic, hypolipidemic (Saracoglu \& Harput, 2012; Wang et al., 2020). In the current study, the cytotoxic activity of the aqueous extract was studied and the iridoid glucosides profile of the extract was determined. Iridoid glycosides may contribute to the cytotoxic effect of the extract. According to Saracoglu and Harput (2012), while aucubin had no activity on $\mathrm{RD}$ and HEp-2 cells, veratroyl catalpol showed cytostatic activity. Veronicoside exhibited a cytotoxic effect on RD and HEp-2 cell lines with $I C_{50}$ values of 153.3 and $355 \mu \mathrm{M}$, respectively. Moreover, amphicoside showed cytotoxic effect only on HEp-2 cell line with $I C_{50}$ values of $340 \mu \mathrm{M}$. In another study, amphicoside had stronger anti-hepatocarcinoma activity on the Hep-G2 cell line than the reference compound, 5-fluorouracil. On the other hand, veronicoside showed strong cytotoxic activity on the proliferation of Hep-G2 cells (Yin et al., 2016).
Phenolics naturally occurring in plants are potential antioxidant compounds and important for the chemotaxonomy of genus Veronica. They may possess cytotoxic activity via their radical scavenging or prooxidant effects (Harput et al., 2012). For that reason, it is important to identify the phenolic profile of $V$. peduncularis. As a result of our isolation studies on phenolic fractions, two compounds; plantamajoside (5) and 4'-O-methylisoscutellarein-7-O-2"-O-(6"'-O-acetyl- $\beta$ $D$-allopyranosyl)- $\beta$-D-glucopyranoside (6) were isolated from aqueous extract of $V$. peduncularis (Figure 3). Compound $\mathbf{6}$ is an acylated 8-hydroxyflavone glycoside. It has been previously reported that allose-containing acylated 8-hydroxyflavone glycosides are important as chemotaxonomic markers, especially for section Alsinebe and section Chamaedyrs (Albach, Jensen, Ozgokce, \& Grayer, 2005; Tomas-Barberan, Grayer-Barkmeijer, Gil, \& Harborne, 1988). The presence of these types of compounds in V. peduncularis (Section Chamaedyrs) was detected chromatographically previously, however, this is the first isolation study of compounds (5 and $\mathbf{6}$ ) from $V$. peduncularis (Albach et al., 2005; Tomas-Barberan et al., 1988). Compound 5 was previously isolated from $V$. orsiniana Ten. (Sin: V. fuhsii) (Ozipek, Saracoglu, Kojima, Ogihara, \& Calis, 1999), and V. beccabunga L. (Jensen, Opitz, \& Gotfredsen, 2011). Compound 6 was isolated from another Veronica species; V. pectinata var. glandulosa (Saracoglu, Harput, et al., 2004) and V. orientalis (Albach et al., 2003). 

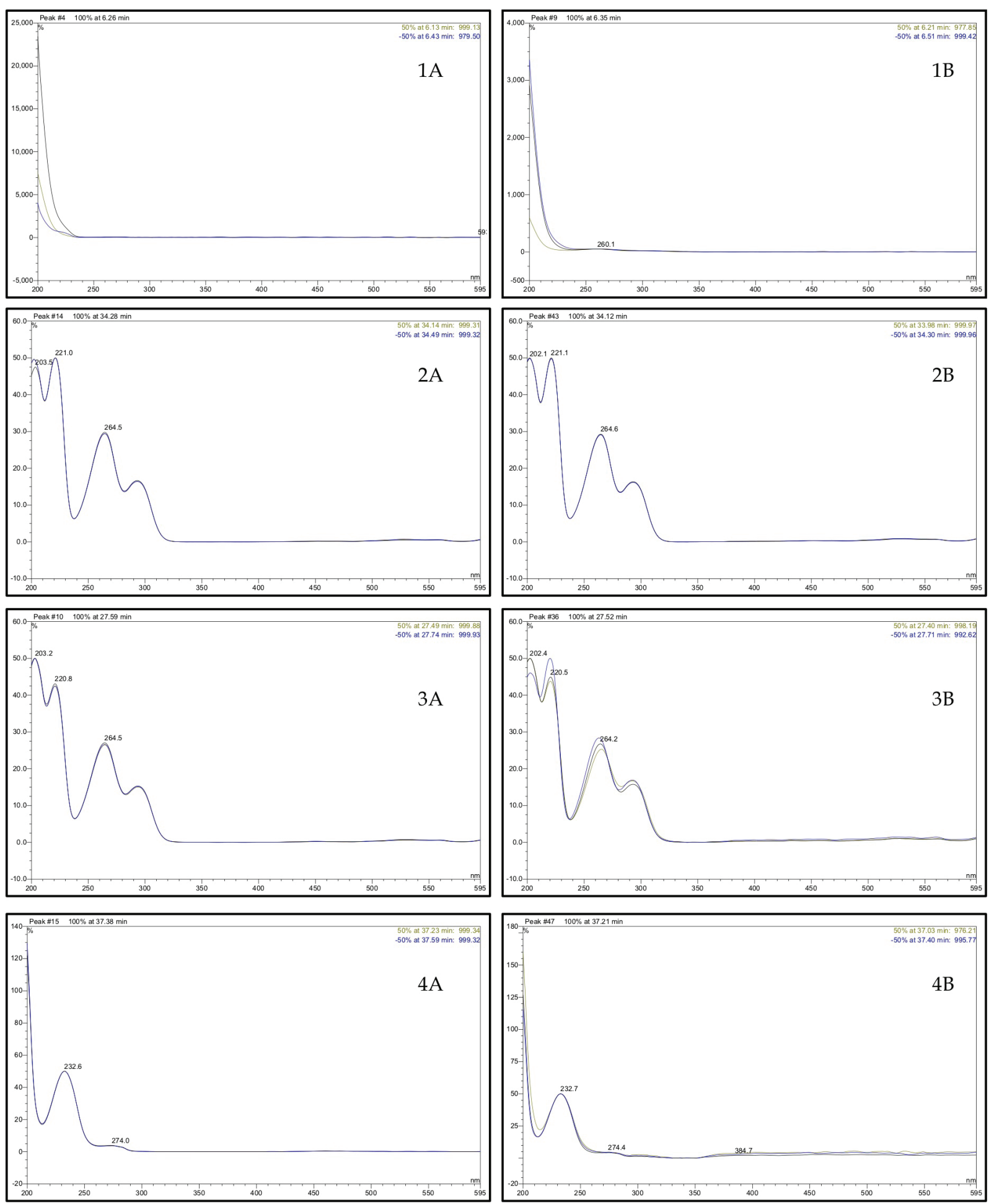

Figure 4. UV spectra of reference compounds (1A-4A) and iridoid glucosides in iridoid fraction of $V$. peduncularis (1B-4B).

\section{CONCLUSIONS}

Cytotoxic activity of $V$. peduncularis was performed on HEp2 and RD cancer cell lines. Four iridoid glucosides, aucubin (1), amphicoside (2), veronicoside (3), and veratroyl catalpol (4) were determined from iridoid fraction of $V$. peduncularis by the HPLC-DAD method. Isolation of plantamajoside (5) and $\quad 4^{\prime}-O-$-methylisoscutellarein-7-O-2"-O-(6"'-O-acetyl- $\beta$-Dallopyranosyl)- $\beta$-D-glucopyranoside (6) were also performed. To the best of our knowledge, this is the first cytotoxic activity and phytochemical study on the titled plant. The current study contributed to chemotaxonomic studies on Veronica species in terms of iridoid glucosides and 6-hydroxyflavone glycosides. 
Peer-review: Externally peer-reviewed.

Author Contributions: Conception/Design of Study- Ü.Ş.H., I.S.; Data Acquisition- Z.D., Y.G., Ü.Ş.H., A.K.P.; Data Analysis/Interpretation- Z.D., Ü.S.H., A.K.P., I.S.; Drafting Manuscript- Z.D., Ü.S..H., I.S.; Critical Revision of Manuscript- Z.D., Y.G., Ü.Ş.H., A.K.P., I.S.; Final Approval and Accountability- Z.D., Y.G., Ü.S.H., A.K.P., I.S.

Conflict of Interest: The authors have no conflict of interest to declare.

Financial Disclosure: This study was supported by by The Scientific and Technological Research Council of Turkey TUBITAK with the grant number $108 \mathrm{~T} 518$.

\section{REFERENCES}

- Albach, D. C., Grayer, R. J., Jensen, S. R., Ozgokce, F., \& Veitch, N. C. (2003). Acylated flavone glycosides from Veronica. Phytochemistry, 64(7), 1295-1301. http://dx.doi.org/10.1016/j.phytochem.2003.08.012

- Albach, D. C., Jensen, S. R., Ozgokce, F., \& Grayer, R. J. (2005). Veronica: Chemical characters for the support of phylogenetic relationships based on nuclear ribosomal and plastid DNA sequence data. Biochemical Systematics and Ecology, 33(11), 1087-1106. http://dx.doi.org/10.1016/j.bse.2005.06.002

- Baytop, T. (1999). Türkiye'de Bitkiler ile Tedavi (Geçmişte ve Bugün) $\left(2^{\text {nd }}\right.$ ed.) [Therapy with medicinal plants in Turkey, Past and Present]. İstanbul, Turkey: Nobel Tip Kitabevleri.

- Fischer, M. A. (1978). 17. Veronica L. In P.H. Davis (Ed.), Flora of Turkey and the East Aegean Islands. Volume Six (pp.489-753), Edinburgh, UK: Edinburgh University Press.

- Fujita, T., Sezik, E., Tabata, M., Yesilada, E., Honda, G., Tanaka, T., \& Takaishi, Y. (1995). Traditional medicine in Turkey VII. Folk medicine in Middle and West Black Sea Regions. Economic Botany, 49, 406-422. http://dx.doi.org/10.1007/Bf02863092

- Graham, J. G., Quinn, M. L., Fabricant, D. S., \& Farnsworth, N. R. (2000). Plants used against cancer - an extension of the work of Jonathan Hartwell. Journal of Ethnopharmacology, 73(3), 347-377. http://dx.doi.org/10.1016/S0378-8741(00)00341-X

- Harput, U. S., Genc, Y., Khan, N., \& Saracoglu, I. (2011). Radical scavenging effects of different Veronica species. Records of Natural Products, 5(2), 100-107.

- Harput, U. S., Genc, Y., \& Saracoglu, I. (2012). Cytotoxic and antioxidative activities of Plantago lagopus $\mathrm{L}$. and characterization of its bioactive compounds. Food and Chemical Toxicology, 50(5), 15541559. http://dx.doi.org/10.1016/j.fct.2012.01.019

- Harput, U. S., Karadeniz, A., Genc, Y., \& Saracoglu, I. (2009). Comparative Bioactivity Studies on Four Veronica species. FABAD Journal of Pharmaceutical Science, 34, 67-72.

- Harput, U. S., Saracoglu, I., Inoue, M., \& Ogihara, Y. (2002). Antiinflammatory and cytotoxic activities of five Veronica species. Biological \& Pharmaceutical Bulletin, 25(4), 483-486. http://dx.doi. org/10.1248/bpb.25.483

- Jensen, S. R., Albach, D. C., Ohno, T., \& Grayer, R. J. (2005). Veronica: Iridoids and cornoside as chemosystematic markers. Biochemical Systematics and Ecology, 33(10), 1031-1047. http://dx.doi. org/10.1016/j.bse.2005.03.001

- Jensen, S. R., Opitz, S. E. W., \& Gotfredsen, C. H. (2011). A new phenylethanoid triglycoside in Veronica beccabunga L. Biochemical Systematics and Ecology, 39(3), 193-197. http://dx.doi. org/10.1016/j.bse.2011.02.008

- $\quad$ Kawada, T., Yoneda, Y., Asano, R., Kan-No, I., \& Schmid, W. (2006). Synthesis of plantamajoside, a bioactive dihydroxyphenylethyl glycoside from Plantago major L. Holzforschung, 60(5), 492-497. http://dx.doi.org/10.1515/Hf.2006.081
- Lenherr, A., Lahloub, M.F. \& Sticher, O. (1984). Three flavonoid glycosides containing acetylated allose from Stachys recta. Phytochemistry, 23(10), 2343-2345.

Mosmann, T. (1983). Rapid colorimetric assay for cellular growth and survival - application to proliferation and cytotoxicity assays. Journal of Immunological Methods, 65(1-2), 55-63. http://dx.doi. org/10.1016/0022-1759(83)90303-4

NCl (National Cancer Institute). (2020, May 8). Antioxidants and Cancer Prevention [online]. Retrieved from https://www.cancer.gov/ about-cancer/causes-prevention/risk/diet/antioxidants-fact-sheet

Olmstead, R. G. (2002). Whatever happened to the Scrophulariaceae? Fremontia, 30(2), 13-22.

- $\quad$ Ozipek, M., Saracoglu, I., Kojima, K., Ogihara, Y., \& Calis, I. (1999). Fuhsioside, a new phenylethanoid glucoside from Veronica fuhsii. Chemical \& Pharmaceutical Bulletin, 47(4), 561-562.

Ravn, H., Nishibe, S., Sasahara, M., \& Li, X. B. (1990). Phenolic compounds from Plantago asiatica. Phytochemistry, 29(11), 3627-3631. http://dx.doi.org/10.1016/0031-9422(90)85289-R

- Salehi, B., Shetty, M. S., Kumar, N. V. A., Zivkovic, J., Calina, D., Docea, A. O., ... Sharifi-Rad, J. (2019). Veronica plants-drifting from farm to traditional healing, food application, and phytopharmacology. Molecules, 24(13). http://dx.doi.org/10.3390/molecules24132454 Saracoglu, I., \& Harput, U. S. (2012). In vitro cytotoxic activity and structure activity relationships of iridoid glucosides derived from Veronica species. Phytotherapy Research, 26(1), 148-152. http:// dx.doi.org/10.1002/ptr.3546

Saracoglu, I., Harput, U. S., \& Ogihara, Y. (2004). Acylated flavone glycosides from Veronica pectinata var. glandulosa and $V$. persica. Turkish Journal of Chemistry, 28(6), 751-759.

- Saracoglu, I., Inoue, M., Calis, I. \& Ogihara, Y. 1995. Studies on constituents with cytotoxic and cytostatic activity of two Turkish medicinal plants, Phlomis armeniaca and Scutellaria salviifolia. Biological \& Pharmaceutical Bulletin, 18(10), 1396-1400.

- $\quad$ Saracoglu, I., Oztunca, F. H., Nagatsu, A., \& Harput, U. S. (2011). Iridoid content and biological activities of Veronica cuneifolia subsp. cuneifolia and V. cymbalaria. Pharmaceutical Biology, 49(11), 11501157. http://dx.doi.org/10.3109/13880209.2011.575790

- Saracoglu, I., Varel, M., Harput, U. S., \& Nagatsu, A. (2004). Acylated flavonoids and phenol glycosides from Veronica thymoides subsp. pseudocinerea. Phytochemistry, 65(16), 2379-2385. http://dx.doi. org/10.1016/j.phytochem.2004.05.011

- $\quad$ Taskova, R. M., Albach, D. C., \& Grayer, R. J. (2004). Phylogeny of Veronica - a combination of molecular and chemical evidence. Plant Biology, 6(6), 673-682. http://dx.doi.org/10.1055/s-2004-830330

Tomas-Barberan, F. A., Grayerbarkmeijer, R. J., Gil, M. I., \& Harborne, J. B. (1988). Distribution of 6-hydroxyflavone, 6-methoxyflavone and 8-hydroxyflavone glycosides in the Labiatae, the Scrophulariaceae and related families. Phytochemistry, 27(8), 2631-2645. http://dx.doi.org/10.1016/0031-9422(88)87034-1

- Wang, C. C., Gong, X., Bo, A., Zhang, L., Zhang, M. X., Zang, E. H., . . Li, M. H. (2020). Iridoids: Research advances in their phytochemistry, biological activities, and pharmacokinetics. Molecules, 25(2). http://dx.doi.org/10.3390/molecules25020287

- Xue, H. B., Chen, K. X., Zhang, L. Q., \& Li, Y. M. (2019). Review of the ethnopharmacology, phytochemistry, and pharmacology of the genus Veronica. American Journal of Chinese Medicine, 47(6), 11931221. http://dx.doi.org/10.1142/S0192415x19500617

- Yin, L., Lu, Q. X., Tan, S. C., Ding, L. S., Guo, Y. R., Chen, F., \& Tang, L. (2016). Bioactivity-guided isolation of antioxidant and anti-hepatocarcinoma constituents from Veronica ciliata. Chemistry Central Journal, 10. http://dx.doi.org/10.1186/s13065-016-0172-1

- Zou, L. C., Zhu, T. F., Xiang, H., Yu, L., Yan, Z. H., Gan, S. C., ... Deng, X. M. (2008). New secoiridoid glycosides from the roots of Picrorhiza scrophulariiflora. Molecules, 13(9), 2049-2057. http://dx.doi. org/10.3390/molecules13092049/ 